\title{
HOMILIA W ARCHIKATEDRZE WARSZAWSKIEJ PODCZAS UROCZYSTEJ EUCHARYSTII POZEGNANIA KSIĘDZA DRA WOJCIECHA DANIELSKIEGO PRZEZ KATOLICKI UNIWERSYTET LUBELSKI W DNIU 30 XII 1985 R.
}

„Nikt z nas nie żyje dla siebie i nikt nie umiera dla siebie: jeżeli bowiem żyjemy, żyjemy dla Pana; jeżeli zaś umieramy, umieramy dla Pana. I w życiu więc i w śmierci należymy do Pana" (Rz $14,7-8)$.

Drodzy w Panu żałobni słuchacze: Bracia i Siostry!

Katolicki Uniwersytet Lubelski na swej sesji wyjazdowej w archikatedrze warszawskiej pragnie oddać hołd swemu profesorowi, człowiekowi wielkiego formatu, prawdziwemu chrześcijaninowi XX-wie$\mathrm{ku}$, gorliwemu kapłanowi naszego Pana, wiernemu synowi Kościoła i Ojczyzny - ks. drowi Wojciechowi Danielskiemu. Dopiero dziś po Jego przejściu do Pana, gdy Bóg zamknąl bogatą księgę Jego życia, uświadamiamy sobie całą niepowtarzalność i wielowymiarowość tej postaci wielkiego świadka Chrystusa naszych czasów. Zgromadziliśmy się więc przy trumnie ks. Wojciecha, by zgłębić tajemnicę człowieka i chrześcijanina, kapłana i nnauczyciela, ale także zgodnie z Jego myślą i wskazaniami, poznać istotne zadania naszego życia z wiary na drodze spotkań człowieka z Bogiem. Poucza nas Apostoł Narodów, że „Bóg jest bliżej człowieka, niż człowiek samego siebie” (por. $\mathrm{Rz}_{\mathrm{z}} 13,11$ ). Ale człowiek jest tak skonstruowany, że to, co dla niego najbliższe, jest zarazem najdalsze i najtrudniejsze do odkrycia. Dlatego droga do Boga, który jest blisko, wydłuża się czasem w nieskończoność.

Ks. Wojciech stanął już u celu tej drogi. Ufamy, że dzięki zawierzeniu Chrystusowi, posłanemu przez Ojca dla zbawienia ludzi, jest z Tym i widzi już chwałę Tego, którego Ojciec umiłował „przed założeniem świata" ( $\mathrm{J}$ 17, 25). Z nadzieją więc patrzymy na ks. Wojciecha jako duchowego przewodnika w naszej wędrówce do Boga, widząc w nim człowieka, który znając sens ludzkich doświadczeń, zgłębił w swoim życiu tajemnicę bliskości Boga, Emmanuela, który jest ciągle $z$ nami. W trzech odsłonach pragniemy przybliżyć sobie bogactwo duchowości ks. Danielskiego, patrząc na Niego jako ochrzczonego człowieka, kapłana i profesora.

1. Chrześcijanin. Przed 50-laty przez swój chrzest w imię Trójcy Przenajświętszej włączony został Wojciech Danielski w nowe życie Boże, w wymiar życia zmartwychwstałego Chrystusa. W mo- 
mencie bowiem chrztu zaczęlo się także Jego zmartwychwstanie i Jego codzienne destylowanie ziemskiego czasu w wieczność. To nowe życie podtrzymywał On w sobie od I Komunii św. przez częste przyjmowanie Eucharystii, zaś od r. 1958 przez codzienne sprawowanie „Wielkiej Tajemnicy Wiary” i wspominanie treści tego _misterium, wyrażonego przez obietnicę samego Chrystusa: „Kto spożywa moje ciało i pije moją krew, ma życie wieczne, a ja go wskrzeszę w dniu ostatecznym" (J 6, 54).

Jak tę codzienną drogę do Boga odnajdywał ks. Wojciech mówi nam On sam w słowach swego testamentu:

„Uczę się ciągle przyjmować z rąk Jego (Boga) niepowodzenia $\mathrm{z}$ wiarą, że mają one sens (od paru lat mówię to $\mathrm{w}$ modlitwie porannej do Chrystusa-Sługi). Dziękuję za takie serdeczne odnalezienie mojego Pana i Przyjaciela, Jezusa Chrystusa: w adoracjach, w dobrych i bliskich ludziach, których otrzymałem, nade wszystko w świętych znakach Słowa Bożego i liturgii, które są mi tak drogie, że sensu poza tym nie widzę: w nauczaniu i pisaniu na KUL, a w praktyce zwłaszcza w KUL-owskim kościele akademickim (wspólnota niedzielna 11.00 kiedyś codziennie 7.30, niezwykła wspólnota Misterium Paschalnego i wielkich dni KUL-u, także pogrzebów) i w oazowych spotkaniach, zwłaszcza moich ukochanych jednomyślnych Braci-Kapłanów, wreszcie moich bliskich wędrowców znad jeziora i z Izabelina - i moich utęsknionych Braci, do których idę już tak długo w Tyńcu" (rps Testament z dnia 18 III 1984 r. s. 2).

Ludzie przechodzący na drugą stronę życia zabierają ze sobą przede wszystkim swój rozwój, to, do czego doszli; to, co z isiebie zrobili, a więc swoją kulturę osobistą i swoje duchowe bogactwo. Dlatego poeta mógl napisać $z$ nostalgią:

Czas, co w przelocie piramidy kruszy,

Wszystko ci weźmie, siły twoje strawi,

Tylko co piękne w twojej duszy,

To ci zostawi.

Ks. Wojciech był czlowiekiem zaufania i nadziei. Jego mistyczne doświadczenie spotkanego Pana stanowiło dla Niego źródło siły i moc napędową w codziennej pracy. Jakże prawdziwie brzmi Jego samoocena wypowiedziana $\mathrm{w}$ specjalnym liście do Matki, odnalezionym wraz z Jego testamentem:

„Tyle się napracowałem i nabiegałem, krótko nacierpiałem, prawie wcale - jakoś wstyd mi wobec naprawdę cierpiących wiele więc MU (Bogu) oddaję się na wszystko" (rps List do Matki s. 1).

Ten heroiczny akt zawierzenia Bogu nawet $w$ chwili rozpierającego ciało cierpienia jest potwierdzeniem Jego gotowości do złożenia całopalnej ofiary z siebie. Mówi także o tajemniczym sensie każdego wysiłku, cierpienia i świadomie podejmowanego aktu ludzkiej miłości. 
Chrześcijanin - jak uczył nas ks. Wojciech - ma oczy zwrócone ku przyszłości, ku Marana tha, czyli przyjściu naszego Pana. Dlatego nie możemy przyjąc dramatycznego stwierdzenia egzystencjalnej filozofii bez Boga, która twierdzi wraz z Martinem Heideggerem, że życie ludzkie jest skierowane tylko ku śmierci (Sein zum Hode). My ehrześcijanie wiemy, że wszystko to, co czyni świat bardziej ludzkim, sprawia, iż jest on bardziej Boży. Zarówno więc nasz rozwój duchowy i nasza doskonałość indywidualna, dobro społeczne a przede wszystkim kultura posiada także wymiar eschatologiczny: zapowiada bowiem i tworzy obszar "nowych niebios i nowej ziemi".

To miłość ludzka, dobro i przyjaźń, których bogactwem dzielił się ks. Wojciech z innymi, ale których także doświadczal od bliźnich kazała Mu napisać: „Dałem i otrzymałem wiele” (Testament s. 2). Ale i u genezy tego podsumowania życiowego leżał autentyzm spotkania Boga w życiu ks. Wojciecha. Chrześcijaninowi, jak mówi współczesny filozof, nie chodzi o to, by dojść do Boga, ale chodzi raczej o to, by rozsunąc zasłonę. Bóg jest poza zasłoną, a zasłoną jesteśmy my sami (J. Tischner).

Każdy $z$ nas rodzi się na tym świecie i żyje na nim. Tu buduje swój dom i tu znajduje swój grób. Ze światem otaczającym nas ludzi łączą nas tysiące nici. Nie żyjemy sami na odludnej wyspie, bo zarówno doświadczenie radości jak i smutku pragniemy dzielić z drugim człowielkiem. Musimy jednak dostrzegać tę potrzebę wzajemnej więzi międzyludzkiej i dziękować Bogu za dobro, które płynie dla nas $z$ ręki drugiego człowieka. O takiej formie wdzięczności, której uczymy się zwłaszcza w czasie sprawowania Eucharystii, mówi także ks. Wojeiech:

„Swiadom, że otrzymałem dobra w domu od Rodziców i Rodzeństwa, od dalszej Rodziny, od Kapłanów, od bliskich moich, starszych (,jak ojców") i młodszych (,jak braci”) świeckich i zakonnych; ile otrzymałem darów przez moje wychowanie, i moją szkołę i moje studia, i moją pracę w parafiach, i tyle lat na KUL-u, i ostatnio w Oazach - że to wszystko pobudza do wdzięczności niesłychanej" (Testament, s. 1).

2. Ka płan. Przejdźmy teraz do drugiego wymiaru życiowej posługi ks. Wojciecha, która wiąże się z Jego udziałem w służebnym kapłaństwie Chrystusa. Ten dar, ale i zadanie, cenił sobie ks. Danielski podczas całej swojej 27-letniej posługi kapłana Chrystusa. Ks. Wojciech odczytywal swoje powołanie w wymiarze wezwania do peinej doskonałości na wzór samego Chrystusa. I tu również możemy się odwołać do słów zawartych w Jego duchowym testamencie:

„Świadom, że zostałem wezwany do świętości i jestem wzywany ciągle w górę tak przeróżnymi sposobami, jakie w swojej Miłości wymyślił i zaplanował Ojciec: przez kapłańską posługę, którą tak kocham - przez rozdawanie siebie: $w$ nauczaniu, i w pisaniu, i w ra- 
dzie, i w rozmowie, i w organizowaniu - i teraz przez cierpienie (...) i jak wierzę jeszcze przez życie mnicha w Tyńcu" (Testament, s. 1).

Nawet zrealizowana tylko w wymiarze duchowym droga do Tyńca, wskazuje na wolę całkowitej dyspozycyjności oraz służby Bogu i ludziom, którą ks. Wojciech wykonywał z taką miłością i taktem, jeszcze na lóżku szpitalnym w Lublinie, wobec przybywających do Niego do spowiedzi chorych. Ta posługa ludziom była dla Niego źródłem radości i bliskości wobec tych zwłaszcza, którzy jak On są szafarzami tajemnic zbawienia:

„Czuję się wybrany dlatego, że spotykałem zwykle przede wszystkim ludzi pobożnych i gorliwych, i z nimi łączył mnie prędko wspólny język, jak wierzę w Duchu Świętym, zwłaszcza: odnowa liturgii, wspólnota kapłanów, odpowiedzialna miłość Kościoła i Narodu, zwłaszcza młodego pokolenia. W tym wszystkim zaś streszcza się dla mnie dzieło Soboru i duch ostatnich papieży. Dlatego nie dziwi się chyba nikt, że moimi najbliższymi braćmi są księża liturgii i oazowcy, i że z tylu biskupami, jak wierzę, rozumiemy się" (Testament, s. 3).

W tę posługę kapłańską włączył ks. Wojciech cały entuzjazm soborowej odnowy, wskazując zarówno duchownym jak i świeckim przyjaciołom, zwłaszcza z Uniwersytetu i kręgów oazowych, że liturgia jest źródlem i szczytem działalności Kościoła (KL 10), trwałą postacią formacji każdego chrześcijanina, zasadą współczesnego duszpasterstwa, Tak jak pierwsze gminy chrześcijańskie uznawał ks. Danielski ukochaną przez siebie liturgię za szkołę wiary, modiitwy, moralności i wspólnoty.

Ale ks. Wojciecha musimy przede wszystkim widzieć w wymiarze - charyzmatyka. Być może nie wielu doceniło Go za życia, gdyż nie dostrzegli tej pneumatologicznej Jego cechy, jako prawdziwego mistrza modlitwy, kierownika ludzkich sumień, a nade wszystko współzałożyciela i ojca Ruchu Światło-Życie. Używam świadomie tych dwóch ostatnich tytułów, by Ruch oazowy wpisał do złotej księgi swoich założycieli imię ks. Wojcięcha Danielskiego. Wszyscy wiemy, że $w$ trudnych chwilach dla Ruchu ks. Wojciech doprowadził oazy do odkrycia istotnego stylu w ich działalności, sprowadzającej się do wypracowania zasad ascezy organicznej i formy formacji chrześcijańskiej, zmierzającej do aktywizacji laikatu w Kościele.

Ks. Wojciech dzięki doświadczeniu i osobistej intuicji zdawał sobie sprawę, jakie cele charyzmatyczne powinny przyświecać Ruchowi Światło-Życie. Podobnie jak każdy ruch w Kościele, tak i ten nie jest organizacją czy instytucją, ale wspólnotą entuzjastów, która pragnie przywrócić do pierwotnej funkcji zaniedbaną sferę życia Kościoła, w tym przypadku aktywną rolę poprawnie uformowanego ucznia Pana. Akcentując ten charyzmatyczny wymiar posługi ludzi świeckich i potrzebę ich formacji na wzorach chrześcijan pierwszych wieków, chcial ks. Wojciech doprowadzić do duchowej przemiany polskiej społeczności kościelnej, rozpoczynając pracę wśród nadziei 
narodu - młodego pokolenia, wiernego Bogu i Ojczyźnie. Tej posłudze wielkiej sprawie budowania Kościoła przez formowanie świadomych członków Mistycznego Ciała Chrystusa poświęcił ks. Danielski wszystkie siły w czasie ostatnich lat życia. Wielu młodych ludzi dobrze oceniało ks. Wojciecha w jego posłudze kapłańskiej. Niezapomniane wrażenie wywarło na nas świadectwo młodej dziewczyny, która jednemu $z$ obecnych tu księży powiedziała: „Jeśli spotkałam kiedyś świętego kapłana, był nim ks. Wojciech Danielski".

3. Profesor. Katolicki Uniwersytet Lubelski ma powód do radości, że z jego środowiska wyszło dwóch współczesnych charyzmatyków: ks. Franciszek i ks. Wojciech, którzy wielkie idee odnowy liturgicznej wypowiedzieli $\mathrm{w}$ prostym zadaniu - wychowania pelnego człowieka na wzór Chrystusa, naszego jedynego Pośrednika u Ojca. Katolicki Uniwersytet Lubelski dziękuje dziś Rodzicom i Rodzinie ks. Wojciecha, a także Archidiecezji Warszawskiej, że ukształtowały tak dojrzalego człowieka, kapłana i pracownika nauki. Wkład ks. Danielskiego w dzieło naukowe KUL był bardzo znaczny. Oprócz Jego osobistego dorobku naukowego sięgającego przeszło pół setki rozpraw, artykułów i sprawozdań naukowych oraz ok. 150 haseł dla Encyklopedii Katolickiej, setek referatów wygłoszonych we wszystkich dziecezjach Polski, sympozjów pastoralno-liturgicznych organizowanych w Krościenku i Lublinie, wreszcie napisanej, ale nie obronionej pracy habilitacyjnej, pt. „Rękopiśmienne agendy, benedykcjonały i pontyfikały w polskich zbiorach bibliotecznych", czy wykonanego $\mathrm{z}$ benedyktyńską pracowitością katalogu z opisem 752 rękopiśmiennych kodeksów liturgicznych, zachowanych w archiwach i bibliotekach całej Polski, był zwłaszcza ks. Wojciech nauczycielem prawdy i głosicielem nadziei chrześcijańskiej. Słuchano Go chętnie zarówno w auli uniwersyteckiej, jak i na ambonie kościoła akademickiego.

Każdy Uniwersytet posiada wielu profesorów etatowych, ale niewielu mistrzów, którzy gromadzą wokół siebie uczniów. Ks. Danielski był prawdziwym mistrzem w znaczeniu tej epoki. Choć nie posiadał habilitacji i profesorskiej nominacji (z wyjątkiem kościelnej) stał się On mistrzemi i autorytetem dla wielu ludzkich sumień, jasnym światłem Kościoła i Ojczyzny, pomagającym ludziom w prostowaniu dróg do Boga i swoich braci. W Jego życiowej drodze odczytujemy realizację wielkiego celu Katolickiego Uniwersytetu Lubelskiego: służby Bogu i Ojczyźnie przez głoszenie prawdy w miłości. Ten cel swojego życia przypomniał ks. Wojciech w swoich ostatnim przesłaniu do Matki:

„Ojciec w Niebie przyjął do końca, dosłownie, moje kapłańskie ofiarowanie siebie, kiedy wiedział, że to dla dobra Kościoła i Polski najlepsze" (List do Matki, s. 1). 
W świetle wiary śmierć dla wierzącego, to misterium przejścia z Chrystusem do nowego życia. Ten fakt zwykli określać starożytni chrześcijanie mianem narodzin dla nieba. Odwołując się do tej terminologii, którą dobrze znał ks. Wojciech, jakże wymownego znaczenia nabiera dzień jego narodzin dla nieba, w wigilię a właściwie już po I nieszporach, czyli w liturgiczny dzień Bożego Narodzenia. Ufamy, że sam Dawca życia ujawnił w ten sposób niezwykły fakt włączenia ks. Wojciecha w tajemnicę Wcielonego Słowa, które stało się Ciałem i zamieszkało wśród nas. Jest to ta nadzieja rodzącego się życia, o którym mówiła ukochana przez ks. Wojciecha, św. Teresa od Dzieciątka Jezus: „Ja nie umieram, tylko wkraczam w życie”. Tę nadzieję udziału w pełni życia głoszą także odnowione obrzędy pogrzebowe, w których podkreśla się, iż w czasie pogrzebu „obchodzi Kościól z wiarą paschalne misterium Chrystusa i modli się, aby ci, którzy przez chrzest zostali zaszczepieni w śmierć i zmartwychwstanie Chrystusa, z Nim przeszli przez śmierć do życia" (Obrzędy pogrzebowe nr 1). Tą nadzieją zachęceni dziękujemy Ci, ks. Wojciechu, za Twoje życiowe przesłanie: za wzór wiary, praktykę miłości i blask chrześcijańskiej nadziei. Dziękujemy Ci za prawdę duchowego testamentu, potwierdzonego świadomą ofiarą służby Bogu i człowiekowi jeszcze $\mathrm{w}$ heroiźmie dwumiesięcznej, powolnej agonii. Dziękujemy $\mathrm{Ci}$ za Twoje życzenie i ostatnie słowa do nas skierowane: „Warto tak żyć, jak mi Pan dał z Wami. Życzę każdemu tego wszystkiego, bo i krzyże tylko $\mathrm{z}$ daleka, w wyobraźni są straszne. Wasz zawsze Pan † z Wami. Ks. Wojciech Danielski" (Testament, s. 10).

Pan, którego ukochałeś całym sercem, niech będzie z Tobą, Wojciechu, i z nami. Amen.

Lublin

KS. JERZY JOZEF KOPEC CP

\section{Ks. Zbigniew Wit}

\section{POŻEGNANIE KS. DRA WOJCIECHA DANIELSKIEGO WARSZAWA 30 XII 1985}

Wojciechu, Bracie Umiłowany, przychodzi mi dzisiaj żegnać Ciebie, jako profesora i współpracownika Katedry Liturgiki Katolickiego Uniwersytetu Lubelskiego. Przez 21 lat przyszło nam spotykać się wspólnie na ubogacających wykładach świetnego erudyty, na budujących godzinach wspólnej modlitwy i dyskusji w Twoim mieszkaniu, a także podczas autentycznie przeżywanej liturgii, gdy jako celebrans 